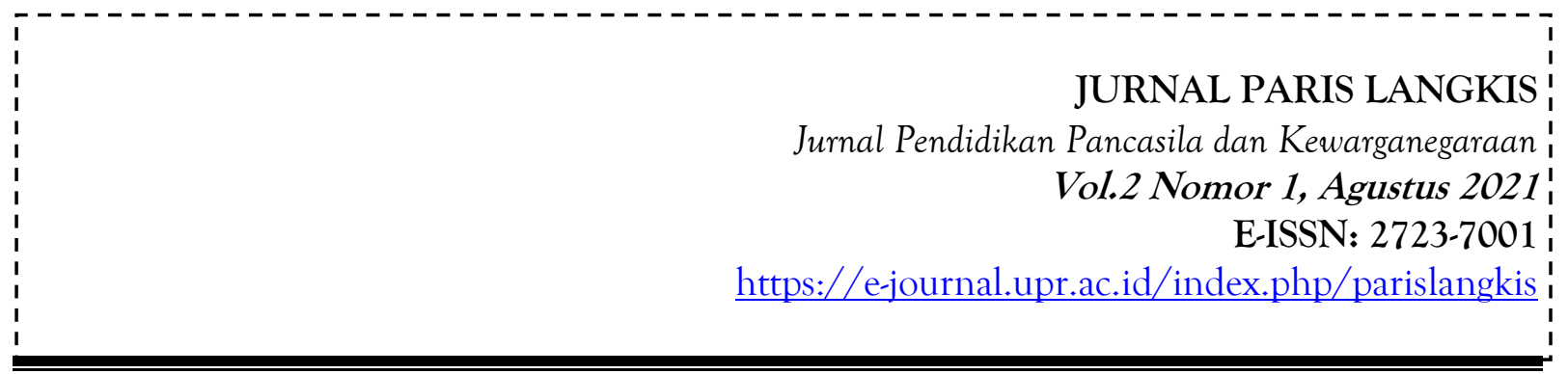

\title{
ANALISIS IMPLEMENTASI PENDIDIKAN PANCASILA BAGI MAHASISWA KEDOKTERAN: STUDI KASUS DI UNIVERSITAS XYZ, TANGERANG, INDONESIA
}

\author{
Juliana Tirza ${ }^{1}$, Wiputra Cendana ${ }^{2}$ \\ ${ }^{1}$ Universitas Pelita Harapan, ${ }^{2}$ Universitas Pelita Harapan \\ ${ }^{1}$ Tangerang, Indonesia, ${ }^{2}$ Tangerang, Indonesia \\ e-mail: ${ }^{1}$ juliana.tirza@uph.edu, ${ }^{2}$ wiputra.cendana@uph.edu
}

\begin{abstract}
Abstrak
Nilai-nilai Pancasila memiliki hubungan yang erat dengan semua bidang profesi, termasuk didalamnya bidang kedokteran. Nilai-nilai Pancasila ini bisa diimplementasikan dalam moral dan etika kedokteran dalam memberi pelayanan kepada pasien. Oleh karena itu, Pancasila juga bisa dijadikan salah satu nilai dasar dalam bidang kedokteran. Setiap butir Pancasila memiliki peranan dan penerapannya masingmasing. Pada kenyataannya, penerapan nilai-nilai Pancasila dalam kedokteran dinilai masih kurang. Hal ini dibuktikan dengan masih adanya isu-isu yang berkaitan dengan etika dan moral kedokteran. Pendidikan Pancasila juga memiliki banyak tantangan. Salah satu penelitian di UNPAR pada tahun 2010 menunjukkan bahwa mahasiswa memiliki persepsi awal yang negatif terhadap mata kuliah Pancasila ini. Mahasiswa beranggapan bahwa pendidikan Pancasila kurang menarik, terlalu teoritis, kaku, dan cenderung membosankan. Tujuan penulisan ini dilakukan untuk memperluas pengetahuan dan memperdalam pemahaman kami akan tanggapan mahasiswa/i Fakultas Kedokteran Universitas XYZ terhadap pendidikan Pancasila. Manfaat penulisan ini dapat bermanfaat bagi para guru dan dosen dalam mencari strategi dan cara untuk meningkatkan antusiasme terhadap pelajaran Pancasila. Hal yang dapat disimpulkan ialah, implementasi Pendidikan Pancasila diuniversitas XYZ sudah berjalan baik, namun masih ada beberapa tantangan besar, diantaranya, mahasiswa memang tidak memiliki motivasi intrinsik untuk mendalami pembelajaran Pancasila yang disebabkan kurangnya ketertarikan dan minat terhadap materi Pancasila. Selain itu, minimnya waktu yang dimiliki oleh mahasiswa Fakultas Kedokteran akibat adanya kesibukan dari mata kuliah materi kedokteran juga menjadi faktor penyebab responden memilih tidak ingin mengikuti Pendidikan Pancasila apabila tidak diwajibkan.
\end{abstract}

Kata kunci: Pendidikan Pancasila; fakultas kedokteran

\section{Paris Langkis}

Vol.2 Nomor 1, Agustus 2021 


\section{A. PENDAHULUAN}

Pancasila merupakan landasan ideologis dan dasar negara Indonesia. Sudah menjadi suatu keharusan dan kewajiban bahwa setiap warga negara Indonesia mampu memahami dan menghayati setiap nilai-nilai yang terkandung dalam kelima sila Pancasila. Salah satu upaya pemerintah agar hal tersebut tetap berjalan adalah melalui pendidikan Pancasila. Kemenristekdikti melalui surat edaran No. 03/M/SE/VIII/2017 menetapkan Pancasila sebagai mata kuliah wajib umum bagi perguruan tinggi bersama dengan mata kuliah pendidikan agama, pendidikan kewarganegaraan, dan bahasa Indonesia. Ditetapkannya Pancasila sebagai mata kuliah wajib umum bagi perguruan tinggi dilakukan berdasarkan UUD 1945 Pasal 27 Ayat 3 dan Pasal 30 Ayat 1 yang menyatakan bahwa seluruh rakyat Indonesia harus ikut serta dalam tindakan bela negara. Selain itu, Undang-Undang Nomor 3 Tahun 2002 Pasal 9 menyatakan bahwa upaya bagi setiap warga negara Indonesia dalam mempertahankan negara dari ancaman baik luar maupun dalam negeri adalah dalam bentuk pengabdian sesuai profesi masing-masing.

Nilai-nilai Pancasila memiliki hubungan yang erat dengan semua bidang profesi, termasuk didalamnya bidang kedokteran. Nilai-nilai Pancasila ini bisa diimplementasikan dalam moral dan etika kedokteran dalam memberi pelayanan kepada pasien. Oleh karena itu, Pancasila juga bisa dijadikan salah satu nilai dasar dalam bidang kedokteran. Setiap butir Pancasila memiliki peranan dan penerapannya masing-masing. Dengan memberikan pendidikan mengenai nilainilai Pancasila, maka diharapkan semua mahasiswa kedokteran dapat memiliki pemahaman yang baik serta dapat mengaplikasikannya dalam profesinya di kemudian hari dengan menjunjung tinggi sumpah dan kode etik dari profesi dokter serta menaati setiap peraturan dan ketentuan yang telah ditetapkan oleh Konsili Kedokteran Indonesia.

Pada kenyataannya, penerapan nilai-nilai Pancasila dalam kedokteran dinilai masih kurang. Hal ini dibuktikan dengan masih adanya isu-isu yang berkaitan dengan etika dan moral kedokteran. Pada tahun 2015, muncul suatu berita berjudul "Sarjana Kedokteran Enggan Mengabdi di Daerah Terpencil". Hal ini menjadi perhatian karena hal tersebut sama saja dengan membeda-bedakan pasien yang bertentangan dengan sila Pancasila. Selain itu, baru-baru ini juga ada berita mahasiswa kedokteran yang memalsukan surat PCR. Hal ini juga menunjukkan masih kurangnya penanaman etika dan Pancasila pada dokter dan mahasiswa kedokteran. Oleh karena itu, Pancasila merupakan mata kuliah yang penting terutama dalam hal ini untuk mahasiswa kedokteran. Penerapan nilai-nilai Pancasila juga dinilai kurang karena mahalnya biaya pada pendidikan kedokteran yang dapat memicu karakter para dokter untuk menjalankan profesinya dengan tujuan seperti mengejar ekonomi yang tidak sesuai dengan nilai Pancasila.

Akan tetapi, pendidikan Pancasila juga memiliki banyak tantangan. Salah satu penelitian di UNPAR pada tahun 2010 menunjukkan bahwa mahasiswa memiliki persepsi awal yang negatif terhadap mata kuliah Pancasila ini. Mahasiswa beranggapan bahwa pendidikan Pancasila kurang menarik, terlalu teoritis, kaku, dan cenderung membosankan. Ditambah lagi, mata kuliah Pancasila ini merupakan mata kuliah wajib sehingga mahasiswa tidak memiliki pilihan lain. Oleh karena itu, makalah ini bertujuan untuk mengetahui dan menganalisis pandangan mahasiswamahasiswi Fakultas Kedokteran Universitas XYZ mengenai pendidikan Pancasila.

Fokus penulisan dari karya tulis ilmiah ini adalah mahasiswa/i Fakultas Kedokteran Universitas XYZ angkatan 2018 yang sedang mengambil mata pelajaran Pancasila. Penulisan ini dilakukan untuk menggali lebih dalam pandangan dan opini mahasiswa/i Fakultas Kedokteran

\section{Paris Langkis}

Vol.2 Nomor 1, Agustus 2021 
terhadap pendidikan Pancasila. Selain itu, penulisan ini meneliti faktor-faktor yang dapat mempengaruhi tanggapan mahasiswa/i fakultas kedokteran terhadap pendidikan Pancasila.

Tujuan penulisan ini dilakukan untuk memperluas pengetahuan dan memperdalam pemahaman kami akan tanggapan mahasiswa/i Fakultas Kedokteran Universitas XYZ terhadap pendidikan Pancasila. Manfaat penulisan ini dapat bermanfaat bagi para guru dan dosen dalam mencari strategi dan cara untuk meningkatkan antusiasme terhadap pelajaran Pancasila, baik antara mahasiswa Fakultas Kedokteran ataupun mahasiswa fakultas lainnya. Penulisan ini dapat membantu pemerintah menerapkan pendekatan yang berbeda dari sebelumnya untuk generasi baru agar mereka dapat melihat betapa pentingnya dan diperlukannya pelajaran Pancasila. Selain itu, penelitian ini dapat membantu peneliti selanjutnya dalam membuat karya tulis ilmiah berikutnya dengan tema yang sama.

\section{B. LANDASAN TEORI}

Pendidikan Pancasila Pendidikan Pancasila merupakan bagian dari mata kuliah/pelajaran Kewarganegaraan. Pendidikan Pancasila sendiri mengajarkan atau berisi mengenai seluruh sejarah terbentuknya Pancasila sampai dengan makna, tujuan, dan penerapan Pancasila sebagai dasar negara Indonesia. Pendidikan Pancasila sangat penting untuk diajarkan dan diterapkan bagi pelajar dimulai dari jenjang pendidikan dasar sampai pada jenjang pendidikan perguruan tinggi atau lanjut (Hendri \& Firdaus, 2021). Hal ini dianggap penting dikarenakan pelajar merupakan bagian dari penerus bangsa Indonesia, sebab itu penting bagi pelajar untuk mengerti arti, makna, dan tujuan Pancasila dalam kehidupan berbangsa dan bernegara di Indonesia. Selain itu, Pendidikan Pancasila merupakan subjek pendidikan yang penting untuk kembali diajarkan bagi pelajar dikarenakan makna Pancasila pada zaman sekarang yang dilihat semakin menurun akan penerapan aspeknya dalam moral masyarakat Indonesia akibat dari arusnya kemajuan globalisasi yang masuk ke Indonesia (PARIS LANGKIS Jurnal Pendidikan Pancasila dan Kewarganegaraan et al., 2021).

Tertulis dalam Undang Undang Nomor 12 tahun 2012 mengenai perguruan tinggi, Pancasila merupakan subjek yang wajib diajarkan pada jenjang pendidikan Diploma dan sarjana. Tujuan diterapkannya kembali Pendidikan Pancasila terkhususnya bagi jenjang perguruan tinggi karena dianggap mahasiswa perlu akan mengerti makna Pancasila dengan sungguh sungguh dalam penerapannya pada praktik klinis profesi yang diambil. Selain itu juga mahasiswa diharapkan dapat mampu menerapkan dasar-dasar Pancasila dalam menyelesaikan berbagai permasalahan eksternal dan internal di Indonesia.

\section{Pancasila dan Profesi Dokter}

Profesi dokter merupakan profesi yang dianggap sebagai profesi dengan pengabdian yang utuh bagi masyarakat luas tanpa membedakan latar belakang ekonomi, sosial, dan budaya. Sehingga ini sering menjadi permasalahan bagi sebagian profesi dokter yang tidak berkeinginan untuk sepenuhnya mengabdi pada masyarakat tanpa memandang latar belakang status ekonomi, sosial, budaya, dan hubungannya dengan Pancasila. Seiring dengan perkembangan dan kemajuan zaman di Indonesia, banyak budaya asing yang masuk dalam berbagai aspek kehidupan masyarakat Indonesia dengan dampaknya tersendiri. Demikian yang terjadi pada perkembangan profesi dokter di Indonesia, dengan banyaknya budaya asing yang masuk dalam aspek

\section{Paris Langkis}

Vol.2 Nomor 1, Agustus 2021 
kedokteran, perkembangan nilai moral pada profesi kedokteran juga dianggap berkurang, sehingga dalam pelayanannya terhadap masyarakat dianggap tidak memadai atau berkurang.

\section{Pancasila dan Sumpah Dokter}

Seperti yang kita ketahui pada sumpah dokter, para calon dokter mengucapkan "Demi Allah (bagi umat Islam, dan dapat diganti sesuai dengan agama dan keyakinan masing-masing individu) Saya Bersumpah”. Hal ini menyatakan bahwa sangat pentingnya seorang dokter mempertanggungjawabkan setiap keputusannya seperti diagnosis, perlakuan, dan keputusan langsung kepada Tuhan Yang Maha Esa atas dasar nilai kemanusiaan dan keTuhanan. Hal-hal nyata yang terjadi pada dunia kedokteran yang dapat melenceng dari sila pertama pancasila yaitu aborsi dan euthanasia.

Untuk contoh sila kedua, dokter merupakan manusia yang berada di tengah kehidupan masyarakat dimana dokter saling berinteraksi dengan orang di sekitarnya, sehingga dokter harus bersedia melakukan kegiatan kemanusiaan/sosial dan tidak melupakan nilai-nilai kemanusiaan yang terpatri dalam diri seorang dokter, contoh kegiatan ini adalah kegiatan khitanan massal, pengobatan gratis, dan lain-lain.

Aplikasi sila ketiga ialah pentingnya seorang dokter mengutamakan bangsa dan negaranya dan menjunjung tinggi nilai nasionalisme dan patriotisme dengan cara mendukung pemerintahan Indonesia dengan melakukan tugasnya sebagai dokter dalam situasi dimana dibutuhkan, contohnya perang. Dokter juga memiliki tanggung jawab untuk meningkatkan pelayanan kesehatan Indonesia agar tidak hilang kepercayaan masyarakat Indonesia dalam kemampuan dokter Indonesia, seperti dengan berobat ke luar negeri.

Sila keempat dapat diaplikasikan dalam hak-hak politik yang dimiliki seorang dokter, seperti berpartisipasi dalam kegiatan politik. Dokter juga harus mementingkan musyawarah mufakat, seperti dalam situasi konsultasi dengan dokter lain terkait penanganan terbaik untuk seorang pasien. Sila kelima diaplikasikan dengan sikap adil yang diterapkan dokter terhadap semua pasien dan sesama manusia. Pengobatan harus dilakukan tanpa memandang latar belakang pasien baik itu ras, agama, kedudukan politik, dan lain-lain.

\section{Pandangan Mahasiswa Terhadap Pancasila}

Pancasila bisa dikatakan sebagai inti jiwa bangsa Indonesia, serta Pancasila harus terus ditafsirkan berdasarkan konteks zaman yang sedang Indonesia jalani. Pendidikan Pancasila cenderung memberi kesan represif dan indoktrinatif, maka mayoritas mahasiswa memiliki perspektif negatif mengenai Pendidikan Pancasila. Pengalaman mahasiswa mengenai Pendidikan Pancasila yang represif memberi kesan bahwa Pancasila terlihat sebagai manipulasi oleh orangorang yang berkuasa. Contoh kesan negatif tersebut terlihat pada penelitian yang dilaksanakan pada mahasiswa Universitas Katolik Parahyangan (UNPAR), dimana Pendidikan Pancasila bersifat syarat kelulusan wajib. Meskipun ada kesan negatif terhadap Pendidikan Pancasila di awal, setelah menjalani Pendidikan Pancasila selama satu semester dapat terlihat perubahan tanggapan mahasiswa ke arah positif mengenai Pancasila. Penelitian tersebut menemukan bahwa pandangan mahasiswa terhadap Pancasila cenderung bersifat negatif dikarenakan Pendidikan Pancasila yang bersifat indoktrinatif, namun setelah menjalani Pendidikan Pancasila, kesan oleh mahasiswa tersebut merubah menjadi kesan positif. Kesimpulan yang ditemukan terdiri dari tiga aspek dalam Pendidikan Pancasila, yaitu materi Pendidikan Pancasila, metode kuliah Pendidikan Pancasila, dan dosen mata kuliah Pendidikan Pancasila. Kesan oleh mahasiswa mengenai Pendidikan Pancasila cenderung tidak menarik dan tidak relevan. Materi yang disampaikan seringkali hanya berupa indoktrinasi apa yang sudah ada,

\section{Paris Langkis}

Vol.2 Nomor 1, Agustus 2021 
tidak disesuaikan dengan keadaan terbaru, dan mahasiswa hanya menerima apa yang disampaikan. Dalam hal ini, isi pembelajaran yang dikaitkan dengan isu terbaru dalam pengajaran sangat baik karena memungkinkan mahasiswa untuk memiliki ketertarikan dan daya pikir yang kritis dan bebas namun terarah. Jika mahasiswa diberi kesempatan untuk berdiskusi dalam lingkungan yang mendukung, maka mahasiswa akan cenderung memiliki tanggapan yang lebih positif terhadap Pendidikan Pancasila dan lebih memungkinkan untuk diterapkan dalam kehidupan sehari-hari.

Selain materi, metode merupakan unsur yang penting dalam Pendidikan Pancasila. Agar bisa memastikan materi disampaikan dengan sempurna, sebaiknya pembawaan kuliah bersifat dialogis daripada monologis. Dialog membantu membangun suasana yang sesuai untuk diskusi dan stimulasi pola pikiran. Metode interaktif membantu memastikan bahwa mahasiswa tidak hanya fokus atau menghafal teori, tetapi memahami isi dari materi itu sendiri. Pemahaman merupakan kata kunci untuk memastikan mahasiswa mendapat dampak positif dari Pendidikan Pancasila.

Interaksi antara dosen mata kuliah Pendidikan Pancasila dan mahasiswa sangat membantu menumbuhkan minat mahasiswa mengenai materi. Dosen yang mampu menciptakan lingkungan yang sesuai, mempersiapkan materi, dan berinteraksi sangat penting untuk pandangan mahasiswa mengenai Pendidikan Pancasila. Dosen yang membantu memPancasilakan kaum muda dan bersifat sebagai teladan yang baik (di luar maupun di dalam lingkungan perguruan tinggi) membantu meningkatkan minat mahasiswa akan Pancasila.

\section{METODE PENELITIAN}

Penelitian ini dilakukan dengan metode kualitatif serang dengan pendekatan yang menitikberatkan pada proses yang pada akhirnya diharapkan menemukan makna dari subjek yang diteliti. Data-data yang diperoleh akan dianalisis untuk merumuskan inti dari persoalan yang terletak pada persepsi mahasiswa terhadap Pendidikan Pancasila. Teknik pengumpulan data yang digunakan adalah kuesioner online (google form). Kuesioner yang disebar berisi empat aspek penting dalam penelitian ini, yaitu pendapat subjek mengenai materi yang tercakup dalam Pendidikan Pancasila, metode yang digunakan dalam proses perkuliahan, dosen yang mengajar Pendidikan Pancasila, dan perspektif mahasiswa terhadap Pendidikan Pancasila yang mencakup motivasi mahasiswa. Keempat aspek penelitian di atas dikemas dalam 17 pertanyaan dimana masing-masing mengandung 2-3 pertanyaan penting yang memerlukan jawaban tertulis. Penyebaran kuesioner ini bertujuan untuk mendapat masukan berupa informasi persepsi akhir mahasiswa terhadap Pendidikan Pancasila. Populasi dari penelitian ini yaitu seluruh mahasiswa Fakultas Kedokteran Universitas XYZ yang sedang mengambil mata kuliah Pancasila. Sampel penelitian ini yaitu 45 mahasiswa-mahasiswi angkatan 2018.

\section{HASIL PENELITIAN DAN PEMBAHASAN}

Berdasarkan kuesioner yang telah disebar secara acak dan diisi oleh 45 mahasiswa/i Fakultas Kedokteran Universitas XYZ, yang berasal dari dua kelas Pendidikan Pancasila yang berbeda, ditemukan bahwa sebanyak 41 (91,1\%) responden mengatakan Pendidikan Pancasila

\section{Paris Langkis}

Vol.2 Nomor 1, Agustus 2021 
perlu dijadikan sebagai mata kuliah. Terdapat beberapa alasan yang mendasari jawaban tersebut yang secara garis besar antara lain karena Pancasila merupakan identitas dan pemersatu bangsa Indonesia untuk mempertahankan eksistensi Negara Kesatuan Republik Indonesia, Pancasila merupakan dasar dan bekal nilai moral dan nilai lainnya bagi mahasiswa dalam menjalani kehidupannya sehari-hari dan profesinya di masa yang akan datang agar tercipta masyarakat yang harmonis termasuk dalam profesi dokter sebagai profesi kemanusiaan, dan Pancasila dapat membimbing masyarakat Indonesia dalam mengikuti perkembangan zaman agar tetap berada pada jalan yang benar. Namun, terdapat 4 responden yang merasa bahwa Pendidikan Pancasila tidak perlu dijadikan mata kuliah karena membebankan dan tidak sesuai dengan jurusan yang diambil serta merasa bahwa Pendidikan Kewarganegaraan saja sudah cukup. Dari alasan-alasan tersebut dapat terlihat bahwa sebagian besar mahasiswa/i sudah mampu memahami esensi dan pentingnya Pendidikan Pancasila itu sendiri dari berbagai aspek sampai ke tahap aspek profesinya. Hal ini juga didukung dengan hasil kuesioner dimana 93,3\% responden merasa bahwa Pendidikan Pancasila ini memang bermanfaat dengan alasan yang kurang lebih sama seperti pada pertanyaan mengapa Pendidikan Pancasila perlu dijadikan sebagai mata kuliah.

Pendidikan Pancasila ini juga dirasakan memberi efek kepada kehidupan 57,8\% responden. Mereka merasa bahwa Pancasila sangat penting untuk kita sebagai penerus bangsa untuk mempertahankan Indonesia di kemudian hari, membuat sadar kembali bahwa Indonesia merupakan bangsa yang beragam dan kaya, dan Pancasila juga sebagai pedoman hidup mereka dalam kehidupan sehari-hari karena menjunjung tinggi nilai-nilai kemanusiaan serta membuat pikiran menjadi lebih kritis dan terbuka. 42,2\% responden lainnya merasa bahwa Pendidikan Pancasila ini bermanfaat, namun tidak memberi efek pada kehidupan mereka.

Materi Pendidikan Pancasila

Terdapat 8,9\% responden menyebut Pendidikan Pancasila sangat menarik dan 64,4\% mengatakan menarik. Mereka beralasan bahwa melalui Pendidikan Pancasila, mereka juga dapat mempelajari sejarah bangsa Indonesia termasuk sejarah pembentukan Pancasila sendiri. Pendidikan Pancasila memberikan pandangan nilai-nilai yang dibutuhkan dalam kehidupan, serta mendorong mahasiswa/i untuk berpikir secara kritis dalam hal menerapkan Pancasila untuk menghadapi keadaan atau isu-isu yang terjadi di saat ini. Dari alasan-alasan tersebut dapat terlihat bahwa materi Pancasila mencakup sangat banyak aspek dalam kehidupan bernegara, dan mahasiswa/i sudah mampu memahami isi materi tersebut dan dapat untuk menerapkannya di berbagai aspek kehidupan.

Hal ini kurang sesuai dengan teori yang ditemukan, dimana pada umumnya mahasiswa/i merasa Pendidikan Pancasila tidak menarik karena isi materinya yang tidak relevan dengan keadaan saat ini. Sedangkan Pendidikan Pancasila di FK UPH selalu dikaitkan dengan keadaan saat ini dan juga didukung dengan diskusi interaktif dan terbuka yang membantu mahasiswa/i lebih memahami dan lebih menerapkan materi dari Pendidikan Pancasila. Namun, Pendidikan Pancasila yang sudah diajarkan sejak jenjang pendidikan terendah membuat beberapa mahasiswa/i lainnya merasa Pendidikan Pancasila saat ini kurang menarik atau bahkan tidak menarik sama sekali karena dari segi teorinya sangat membosankan dan diulang-ulang. Hal ini didukung dengan hasil jawaban pertanyaan lain dimana $60 \%$ responden mengatakan bahwa materi Pendidikan Pancasila biasa saja (karena diulang-ulang) dan 40\% responden mengatakan bahwa materi Pendidikan Pancasila banyak (karena mencakup berbagai aspek).

Metode Belajar Mengajar Pancasila

\section{Paris Langkis}

Vol.2 Nomor 1, Agustus 2021 
Seperti disebutkan sebelumnya dimana Pendidikan Pancasila di FK UPH selalu dikaitkan dengan keadaan saat ini (relevan) dan adanya diskusi antara dosen dan sesama mahasiswa membuat $6,7 \%$ responden mengatakan bahwa metode pengajaran sangat menarik, sedangkan $55,6 \%$ responden mengatakan menarik. Selain itu, mereka juga berpendapat bahwa metode tersebut membuat penyampaian materi yang biasanya dianggap diulang-ulang dan membosankan menjadi lebih jelas, singkat, dan padat, disertai video-video dan kuis-kuis interaktif yang membuat pengajaran menjadi lebih terasa bermanfaat. Namun, masih ada $28,9 \%$ responden lainnya yang merasa metode pengajaran kurang menarik dikarenakan adanya tugas yang terkadang terlalu banyak dan $8,9 \%$ responden lainnya yang merasa metode pengajaran tidak menarik sama sekali karena membosankan dan dianggap tidak penting. Dari hal-hal di atas dapat diambil kesimpulan bahwa sebagian besar mahasiswa/i beranggapan bahwa metode penyampaian materi sudah cukup menarik, namun terdapat keluhan di metode penugasan. Hal ini didukung dengan $84,4 \%$ responden yang menyatakan bahwa metode yang saat ini digunakan untuk mempresentasi materi perkuliahan bermanfaat, sedangkan $64,4 \%$ mengatakan tidak bermanfaat. Keadaan ini sangat sesuai dengan yang disebutkan pada teori dimana metode pengajaran dialogis dan interaktif lebih dianjurkan dibanding metode monologis. Dengan demikian, dapat disimpulkan bahwa karena metode pengajaran sudah menarik dan sesuai, mahasiswa sudah cukup mendapatkan dampak positif dari Pendidikan Pancasila ini.

Dosen Pendidikan Pancasila

Secara keseluruhan tanggapan mahasiswa terhadap dosen sangatlah baik. Sebanyak 68,9 $\%$ responden mengatakan dosen membantu mahasiswa memahami materi perkuliahan Pendidikan Pancasila dan 24,4\% responden menyatakan dosen sangat membantu. 64,4\% responden berpendapat bahwa dosen mengajar secara interaktif dan 33,3\% berpendapat bahwa dosen sangat interaktif. Hampir seluruh responden, sebanyak 95,6\%, mengatakan bahwa dosen telah membuka wawasan mereka tentang Pancasila dan 97,8\% responden mengatakan bahwa dosen mengajarkan nilai-nilai Pancasila dengan menarik contoh-contoh yang relevan. Hal ini dikarenakan dalam mengajari mata kuliah Pancasila, dosen menggunakan video, kuis interaktif, dan diskusi terbuka baik antara dosen dengan mahasiswa maupun antara sesama mahasiswa/i. Hal ini sesuai dengan yang disebutkan sebelumnya bahwa interaksi antara dosen dengan mahasiswa/i akan menumbuhkan minat mahasiswa mengenai materi, terlihat dari $64,4 \%$ responden yang menyatakan bahwa materi mata kuliah Pancasila bersifat menarik.

Mahasiswa dalam Kelas Pendidikan Pancasila

Seperti yang tertera dalam Undang-Undang Nomor 12 Tahun 2012, Pendidikan Pancasila merupakan mata kuliah yang wajib pada perguruan tinggi. Sebagian besar responden, sebanyak 60\%, mengatakan tidak akan mengikuti Pendidikan Pancasila jika tidak diwajibkan. Responden beralasan bahwa sudah terdapat banyak mata kuliah lain yang juga bersifat wajib sehingga tidak memiliki waktu di antara kesibukan kuliah untuk sepenuhnya berpartisipasi dalam mata kuliah Pancasila. Responden juga mengatakan sebelumnya sudah pernah mendapatkan pendidikan tentang kewarganegaraan dan Pancasila sejak jenjang Sekolah Dasar hingga Menengah Atas, serta anggapan bahwa mata kuliah Pendidikan Pancasila tidak relevan dengan jurusan yang sedang diminati, yaitu kedokteran.

$40 \%$ responden lainnya mengatakan akan tetap mengikuti mata kuliah Pendidikan Pancasila meskipun tidak diwajibkan karena seluruh aspek kehidupan di Indonesia bermuara dari Pancasila sehingga perlu dipahami dan disadari untuk meningkatkan moral kita semua sebagai warga negara. Mayoritas dari mahasiswa/i menyatakan sudah merasa cukup mengenal

\section{Paris Langkis}

Vol.2 Nomor 1, Agustus 2021 
Pancasila, namun terdapat juga yang berkata belum dapat dipahami dan diaplikasikan dengan baik, sehingga ingin ikut serta dalam mata kuliah Pancasila untuk mempelajarinya lebih lanjut. Dalam kenyataan, pemahaman dan penerapan Pancasila merupakan suatu proses pembelajaran seumur hidup, baik pada usia bersekolah maupun tidak bersekolah, sehingga dibutuhkan kesadaran atau penekanan lebih akan pentingnya Pancasila di setiap jenjang pendidikan maupun kehidupan sehari-hari masih kurang.

Jika dilihat relevansi mata kuliah Pancasila di bidang kedokteran, sebagian besar responden, sebanyak $86,7 \%$, menyatakan terdapat relevansi jelas sedangkan 13,3\% menyatakan tidak terdapat relevansi. Dari 86,7\% responden tersebut, dinyatakan bahwa nilai-nilai Pancasila bersifat penting dan harus diaplikasikan dalam pekerjaan profesi kedokteran. Responden lain yang menyatakan mata kuliah Pancasila tidak memiliki relevansi dengan kedokteran beralasan bahwa Pendidikan Pancasila merupakan indoktrinasi dari bahan sebelumnya dan materi yang diberikan tidak disesuaikan dengan perkembangan politik yang terjadi di saat ini, serta tidak akan digunakan dalam bidang non-politik seperti kedokteran.

Dalam kenyataan, nilai-nilai yang didapatkan dari mata kuliah Pancasila dapat diterapkan langsung dalam profesi kedokteran karena seorang dokter tentu harus menjunjung tinggi unsur moral dan kemanusiaan dalam melayani pasien-pasiennya. Setiap tindakan yang diambil harus dilakukan dengan dengan tujuan untuk menolong sesama manusia tanpa maksud untuk mencelakai. Seorang dokter juga harus menjunjung tinggi nilai keadilan dan kejujuran dalam menyediakan pelayanan kesehatan kepada pasiennya tanpa memperlihatkan budaya, kultur, atau etnisitas. Setiap dokter yang berpraktik akan terikat oleh sumpah dokter, dimana nilai-nilai ketuhanan dan kemanusiaan yang terdapat pada sila pertama dan kedua wajib ditaati sebagai pedoman ketika mengambil tindakan dalam klinik. Dari hal ini dapat dilihat bahwa masih terdapat mahasiswa/i yang belum memahami keterkaitanan Pancasila dengan aspek kehidupan masa kini, terutama bidang kedokteran.

Saat ditanyakan mengenai motivasi intrinsik dalam pembelajaran Pancasila, hanya 25 responden $(55,6 \%)$ yang mengatakan memiliki motivasi untuk ikut serta dalam pembelajaran. Motivasi intrinsik merupakan suatu motivasi atau dorongan yang berasal dari diri sendiri tanpa dipengaruhi faktor ekstrinsik seperti unsur kewajiban. Berbagai dorongan untuk mempelajari Pancasila lebih dalam meliputi keinginan menggali esensi dari Pancasila dan lebih menguasai cara menerapkannya dalam kehidupan sehari-hari agar dapat menjadi warga negara yang lebih baik dan bermoral, serta keinginan untuk memperluas wawasan diri mengenai negara Indonesia lebih lanjut, terutama sejarah perjuangan dan latar belakang dari pembentukan Pancasila. Terdapat juga perasaan tanggung jawab sebagai generasi muda yang akan menjadi penerus bangsa Indonesia sehingga penting sekali untuk memiliki pemahaman dan penerapan isi Pancasila yang baik agar nilai-nilai dari Pancasila tidak luntur dalam masyarakat dan perjuangan pahlawanpahlawan Indonesia tidak akan sia-sia.

Di sisi lain, mayoritas responden yang mengatakan tidak memiliki motivasi untuk mendalami pembelajaran Pancasila merasa demikian karena kurang tertarik dan tidak berminat terhadap materi Pancasila. Sebanyak 33,3\% responden menjawab hal yang sama. Responden kurang merasa tertarik terhadap pembelajaran Pancasila karena telah mendapatkan mata pelajaran pendidikan kewarganegaraan dan sejarah sejak tingkat SD hingga SMA. Oleh karena itu, responden menganggap sudah memiliki pemahaman dasar yang cukup dan tidak membutuhkan pengajaran lebih dalam, terutama di tengah-tengah kesibukan untuk memenuhi persyaratan mata kuliah lain. Namun, terdapat responden yang sebaliknya merasa dirinya kurang

\section{Paris Langkis}

Vol.2 Nomor 1, Agustus 2021 
menguasai materi yang diberikan saat tingkat SMA dan ingin mempelajarinya lebih dalam di mata kuliah Pancasila.

Hasil yang diperoleh dari kuesioner ini memiliki kesamaan dengan penelitian sebelumnya yang dilakukan pada mahasiswa Universitas Katolik Parahyangan (UNPAR). Tentu sifat mata kuliah Pancasila yang wajib sebagai syarat kelulusan pada awalnya akan menimbulkan pandangan represif dan indoktrinasi di antara mahasiswa/i, namun mayoritas dari responden berupa mahasiswa/i Fakultas Kedokteran yang telah menjalani pembelajaran Pancasila menunjukkan kesan positif dan keminatan terhadap Pancasila, meskipun sebelumnya telah mendapatkan jenis pendidikan serupa sewaktu SMA. Pengenalan dan pemaparan materi secara efektif memiliki peran penting dalam menentukan minat mahasiswa/i untuk melanjuti pembelajaran Pancasila kedepannya. Dalam hal ini, ketertarikan dan minat mahasiswa/i dapat berasal atau didukung penyampaian materi yang jelas, bermanfaat, dan bersifat interaktif dibandingkan sekedar hafalan teori, disertai dosen yang mengajar dapat mengaitkan materi dengan keadaan politik dan isu-isu yang berkembang saat ini. Sebaliknya, kehilangan minat atau motivasi mengikuti pembelajaran Pancasila berakar dari pandangan mata kuliah Pancasila sebagai pengulangan mata pelajaran pendidikan kewarganegaraan yang juga diwajibkan sejak tingkat SD hingga SMA. Mahasiswa/i merasa sudah cukup memahami materi Pancasila dan tidak akan memperoleh ilmu atau wawasan baru dari mata kuliah tersebut. Penurunan motivasi ini semakin diperkuat oleh tingkat kesibukan dan kepadatan jadwal yang cenderung dialami oleh mahasiswa/i Fakultas Kedokteran, dimana mahasiswa/i merasa jika mata kuliah Pancasila tidak diwajibkan, mereka lebih dapat meluangkan waktu untuk pembelajaran mata kuliah kedokteran, mengerjakan tugas, atau untuk beristirahat.

Jika dilihat relevansi mata kuliah Pancasila di bidang kedokteran, sebagian besar responden, sebanyak 86,7\%, menyatakan terdapat relevansi jelas sedangkan 13,3\% menyatakan tidak terdapat relevansi. Responden menyatakan bahwa nilai-nilai yang didapatkan dari mata kuliah Pancasila dapat diterapkan langsung dalam profesi kedokteran karena seorang dokter tentu harus menerapkan nilai-nilai Pancasila, terutama unsur moral dan kemanusiaan, dalam berinteraksi dengan pasien-pasiennya. Nilai-nilai dari Pancasila memiliki hubungan yang erat dengan bidang kedokteran dan responden beranggapan bahwa Pancasila memiliki nilai-nilai yang dapat diaplikasikan untuk memberikan pelayanan kesehatan yang adil tanpa melihat latar belakang pasien, serta setiap tindakan yang diambil harus menjunjung tinggi nilai kemanusiaan khususnya untuk menolong sesama manusia.

\section{E. KESIMPULAN}

Berdasarkan analisis dari studi yang dilakukan kepada mahasiswa angkatan 2018 dari Fakultas Kedokteran Universitas XYZ yang mengikuti program Pendidikan Pancasila, terdapat beberapa kesimpulan yang dapat diambil. Pandangan mayoritas mahasiswa Fakultas Kedokteran Universitas XYZ angkatan 2018 mengenai Pendidikan Pancasila memberikan kesan yang positif. Sebagian besar mahasiswa menyatakan Pancasila sebagai mata kuliah yang diperlukan. Mahasiswa mampu memahami esensi dan pentingnya Pendidikan Pancasila dari berbagai aspek hingga tahap aspek profesinya. Lebih dari setengah mahasiswa merasakan efek dari pendidikan ini ke dalam kehidupan karena materi Pancasila mencakup sangat banyak aspek dalam kehidupan bernegara, dan mahasiswa/i sudah mampu memahami isi materi tersebut serta menerapkannya di berbagai aspek kehidupan.

\section{Paris Langkis}

Vol.2 Nomor 1, Agustus 2021 
Mengenai materi yang diajarkan, mahasiswa cenderung mengatakan bahwa materi yang disampaikan bersifat biasa saja. Faktor yang melatarbelakangi hal tersebut adalah materi yang disampaikan merupakan pengulangan materi yang pernah didapatkan dari jenjang pendidikan sebelumnya dan membosankan serta terlalu banyak. Hal ini menyebabkan materi yang disampaikan kurang dianggap menarik oleh mahasiswa. Namun, dosen Pendidikan Pancasila di FK UPH berhasil membuat metode penyampaian materi menjadi cukup menarik yang didukung dengan hasil dari studi kami dimana dinyatakan bahwa sebanyak 64,4\% berpendapat bahwa dosen mengajar secara interaktif dan lebih dari $90 \%$ responden menyatakan dosen berhasil menambah wawasan mahasiswa mengenai Pancasila dan mengajarkan nilai Pancasila secara aplikatif. Hasil analisis juga menunjukan bahwa mahasiswa menyatakan adanya relevansi yang jelas dan penerapan langsung dalam profesi kedokteran, sebagaimana seorang dokter wajib menerapkan nilai Pancasila terutama unsur moral dan kemanusiaan. Dengan demikian, dapat disimpulkan bahwa karena metode pengajaran sudah menarik dan sesuai, mahasiswa sudah cukup mendapatkan dampak positif dari Pendidikan Pancasila ini.

Mayoritas responden menyatakan tidak akan mengikuti mata kuliah Pendidikan Pancasila apabila tidak diwajibkan. Hal ini terkait dengan hasil analisis dimana hampir setengah dari seluruh responden tidak memiliki motivasi intrinsik untuk mendalami pembelajaran Pancasila yang disebabkan kurangnya ketertarikan dan minat terhadap materi Pancasila. Selain itu, minimnya waktu yang dimiliki oleh mahasiswa Fakultas Kedokteran akibat adanya kesibukan dari mata kuliah materi kedokteran juga menjadi faktor penyebab responden memilih tidak ingin mengikuti Pendidikan Pancasila apabila tidak diwajibkan. Namun, karena kesadaran mahasiswa akan adanya relevansi yang erat dan kewajiban untuk menerapkan nilai Pancasila ke dalam profesi dokter seperti dalam memberikan pelayanan kesehatan yang adil serta menjunjung tinggi nilai kemanusiaan dalam setiap tindakan khususnya untuk menolong sesama, mahasiswa menganggap bahwa Pancasila itu sebagai mata kuliah yang penting dan wajib diikuti.

\section{DAFTAR PUSTAKA}

Anwar, F. (2021). Mahasiswa Kedokteran Pemalsu Surat Tes PCR Terancam DO. Detikhealth. Retrieved from https://health.detik.com/berita-detikhealth/d-5326225/ mahasiswakedokteran-pemalsu-surat-tes-pcr-terancam-do

Buamona, H. (2017). Pancasila Sebagai Nilai Dasar Profesi Dokter. Jurnal Hukum Novelty, 8(1), 121-136. doi: 10.26555/novelty.v8i1.a6562

Hendri, H. I., \& Firdaus, K. B. (2021). Resiliensi Pancasila Di Era Disrupsi: Dilematis Media Sosial Dalam Menjawab Tantangan Isu Intoleransi. Jurnal Paris Langkis, 1(2), 36-47.

Kementerian Pendidikan dan Kebudayaan Republik Indonesia. (2017). Surat Edaran Menristekdikti: Penguatan Pendidikan Pancasila dan MKWU pada Pendidikan Tinggi. Direktorat Jenderal Pembelajaran dan Kemahasiswaan.

Laku, S., \& Bolo, A. (2010). Pandangan Atau Tanggapan Akhir Peserta Mata Kuliah Pendidikan Pancasila Terhadap Pendidikan Pancasila Di UNPAR. Lembaga Penelitian Dan Pengabdian Masyarakat Universitas Katolik Parahyangan.

PARIS LANGKIS Jurnal Pendidikan Pancasila dan Kewarganegaraan, J., Femina Sitanggang, L.,

\& Lion, E. (2021). PERSPEKTIF MAHASISWI PRODI PPKn UNIVERSITAS

\section{Paris Langkis}

Vol.2 Nomor 1, Agustus 2021 
PALANGKA RAYA TETANG BUDAYA POPULER KOREA (K-POP) TERHADAP GAYA HIDUP. Jurnal Paris Langkis, 1(2), 23-35. https://ejournal.upr.ac.id/index.php/parislangkis

Subagyo, A. (2014). Pendidikan Pancasila untuk Mahasiswa Kedokteran. Penerbit Alfabeta.

Subagyo, A., S.IP., M.Si. (2014). Pendidikan Pancasila untuk Mahasiswa Kedokteran. ALFABETA. 